$1-1-1936$

\title{
Mass feeding of sheep with copper sulphate and salt to control gastro-intestinal parasites
}

J.H. Rietz

Follow this and additional works at: https://researchrepository.wvu.edu/ wv_agricultural_and_forestry_experiment_station_bulletins

\section{Digital Commons Citation}

Rietz, J. H., "Mass feeding of sheep with copper sulphate and salt to control gastro-intestinal parasites" (1936). West Virginia Agricultural and Forestry Experiment Station Bulletins. 271.

https://researchrepository.wvu.edu/wv_agricultural_and_forestry_experiment_station_bulletins/272 @ WVU. It has been accepted for inclusion in West Virginia Agricultural and Forestry Experiment Station Bulletins by an authorized administrator of The Research Repository @ WVU. For more information, please contact ian.harmon@mail.wvu.edu. 
West Virginia University Libraries

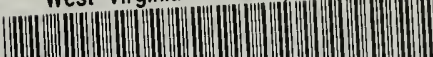

(n.

308021005212247 



\section{MASS FEEDING OF SHEEP WITH COPPER SULPHATE AND SALT TO CONTROL GASTRO-INTESTINAL PARASITES}

By J. H. RIETZ

AGRICULTURAL EXPERIMENT STATION

COLLEGE OF AGRICULTURE, WEST VIRGINIA UNIVERSITY

F. D. FROMME, Director MORGANTOWN 


\section{Agricultural Experiment Station StafF}

C. S. BOUCHER, Ph. D., President of the University

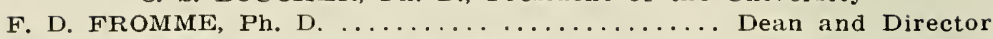
GERALD JENNY, M. S., Agricultural Editor....JOHN C. .JOHNSTON, Chief Clerk

\section{AGRONOMY AND GENETICS}

R. J. Garber, Ph. D. Agronomist and Geneticist

W. H. Pierre, Ph. D. Associate Áronomist

T. C. McIlvaine, Ph. D. ${ }^{*} \dagger$ Associate Agronomist

G. G. Pohlman, Ph. D. Assistant Agronomist

C. R. Burnham, Ph. D. Assistant Geneticist

J. A. Rigney, M. S. Assistant in Agronomy

ANIMAL HUSBANDRY

E. A. Livesay, D. Sc. Animal Husbandman

C. V. Wilson, M. S. Assistant Animal Husbandman

J. H. Longwell, M. A. Assistant Animal Husbandman

R. H. Tuckwiller, B. S. Agr.* Assistant Animal Husbandman

J. H. Rietz, D. V. M. Associate Veterinarian

E. T. Wightman, M. S. Assistant Pouitry Husbandman

T. B. Clark, M. S. Assistant Poultry Husbandman

\section{CHEMISTRY}

R. B. Dustman, Ph. D. Agricultural Chemist

C. E. Weakley, Jr., M. A. Assistant Chemist

A. H. VanLandingham, Ph. D. Assistant Chemist

I. J. Duncan, M. S. Assistant in Agricultural Chemistry

\section{DAIRY HUSBANDRY}

H. O. Henderson, Ph. D. Dairy Husbandman

L. M. Thurston, Ph. D. Associate Dairy Husbandman

G. A. Bowling, M. S. Assistant Dairy Husbandman

R. A. Ackerman, M. S. $\ddagger$ Assistant Dalry Husbandman

\section{ENTOMOLOGY}

L. M. Peairs, Ph. D. Entomologist

W. E. Rumsey, B. S. Agr. Assistant Entomologist

\section{FARM ECONOMICS}

W. W. Armentrout, Ph. D. Farm Economist

F. D. Cornell, Jr., M. S. Assistant Farm Economist

C. H. Bruce, B. S. Assistant in Farm Economics

W. P. Gainer. B. S. Agr. Assistant in Farm Economics

L. F. Herrmann, M. S. Assistant in Farm Economics

\section{HOME ECONOMICS}

Rachel H. Colwell, M. A. Home Economist

Hazel C. Cameron, M. A. Research Specialist in Nutrition

\section{HORTICULTURE}

H. E. Knowlton, Hh. D. Horticulturist

K. C. Westover, M. S. Assistant Horticulturist

L. P. Batjer, Ph. D. Assistant Horticulturist

E. N. McCubbin, M. A. Assistant in Horticulture

A. P. Dye, M. S. Agr. Assistant in Horticulture

W. H. Childs, M. S. Assistant in Horticulture

\section{PLANT PATHOLOGY}

C. R. Orton, Ph. D Plant Pathologist

L. H. Leonian. Ph. D. Mycologist

Anthony Berg, M. S. Associate Plant Pathologist

F. J. Schneiderhan, Ph. D. $\dagger \dagger$ Associate Plant Pathologist

*In cooperation with the U. S. Department of Agriculture, Washington, D. C. tIn charge of the Lakin Experiment Farm. Lakin, W. Va.

In charge of the Reymann Memorial Farms, Wardensville, W. Va

ttIn charge of the University Experiment Farm, Kearneysville, W. Va. 


\title{
Mass Feeding of Sheep With Copper Sulphate and Salt to Control Gastro-Intestinal Parasites
}

\author{
by J. H. RIETZ
}

T HE QUESTION OF MASS FEEJING of sheep with a mixture of copper sulphate with salt or with grain to control gastrointestinal parasites is raised frequently. Mass feeding of any anthelmintic that will control internal parasites would be the ideal method of control.

The object of this experiment was to find a method of administration of the anthelmintic easier than the regular system of drenching, which has been proved effective (Hutcheson (6), Bell (1), Nighbert ( $\tau$ ), Hardy and Schmidt (5), Rietz (8)), and thereby to bring about a more general use of control measures.

\section{PLAN OF THE EXPERIMENT}

In this experiment 20 ewes were allowed access to a mixture of 1 pound of copper sulphate to 30 pounds of salt; 7 ewes were used as treated controls and drenched at intervals of 21 days with 3 ounces of a $11 / 2 \%$ solution of copper sulphate; and 4 ewes were left as untreated controls.

The 20 sheep receiving the copper-sulphate-salt mixture were pastured in a field of approximately 12 acres. When the grass became inadequate to provide proper feed it was supplemented by grain or grain and hay. The grain used was a mixture of equal parts of shelled corn and oats. The hay was a fair-to-good grade of alfalfa.

The copper-sulphate-salt mixture was placed in a box in the barn for protection from moisture and was otherwise protected from contamination and waste by the sheep. The 20 sheep consumed approximately 10 pounds of the copper-stulphate-salt mixture per month or one-half pound each per month throughout the experiment. This is approximately the normal salt consumption for these sheep when allowed access to salt ad libitum (Evvard, J. M., et al. (4), $\operatorname{Bell}(2)$ ).

The pasture over which these sheep grazed had been used continuously during the three previous years as quarters for sheep used in investigational work on parasites. Fifteen species of parasites were identified by autopsy and laboratory findings during these investigations (8). Consequently the range was considered heavily infested.

The 7 treated and 4 untreated controls were pastured together in an adjoining pasture of approximately 6 acres, with all the conditions approximating as nearly as possible those in the pasture used for the 20 sheep fed the copper-sulphate-salt mixture. Salt was fed to this group ad libitum, the consumption being approximately onehalf pound for each sheep per month. 


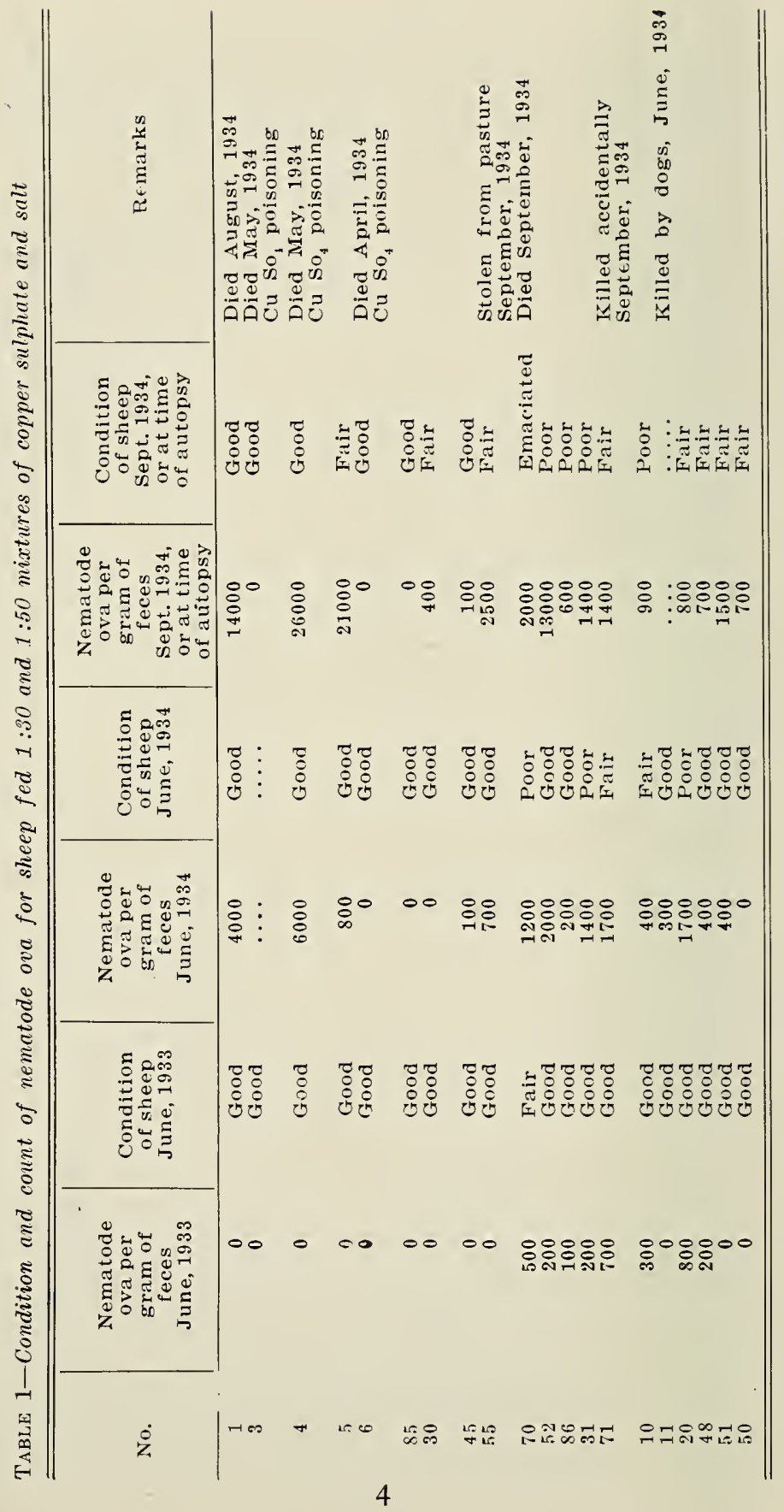


A count of the nematode ova in the feces of each sheep in the three groups was made (Stoll (9)) at the beginning, at intervals during, and at the termination of the experiment.

\section{RESULTS OF THE EXPERIMENT}

The trials in which the mixture of 1 pound of copper sulphate to 30 pounds of salt was used began in June 1933 and ended in June 1934. Table 1 shows the condition of each sheep and the count of nematode ova at the beginning and end of this period. The average count of nematode ova per gram of feces was 150 in June 1933, the beginning of the experiment, and 1100 in June 1934, the end of the experiment.

On the morning of April 6,1934, sheep no. 6 of the lot allowed free access to the copper-sulphate-salt mixture was found dead in the pasture. This animal was apparently normal when fed grain on the evening of April 5. The autopsy showed the carcass to be in a good state of nourishment. There was an ample layer of fat over the body and the omentum contained much fat. All the body tissues showed a marked icterus. The liver was enlarged, soft, and yellow; kidneys swollen, dark, and soft; bladder hemorrhagic, contents bloody. No other marked changes were noted except the general icterus (Boughton and Hardy (3)). The tentative diagnosis of poisoning from feeding an excessive amount of copper sulphate was made.

On the morning of May 10 sheep no. 3 was found dead in the pasture. No previous illness had been noted by the attendant. The autopsy showed the carcass to be in good condition; tissues markedly icteric; liver enlarged, soft, and yellow; kidneys swollen, dark, and soft. The pelvis of the kidneys contained a light blue precipitate. The bladder was congested and empty. The yellow color was the only change noted in the other organs.

Analysis* of the liver and kidney of sheep no. 3 showed a deposit of 140 milligrams of copper per kilogram of liver. Qualitative analysis of the blue precipitate from the kidney showed this to be a heavy deposit of copper. The diagnosis was poisoning from feeding an excessive amount of copper sulphate.

Table 2 shows the condition of each sheep and the count of nematode ova per gram of feces for the 7 treated control sheep at the beginning and end of the experiment. The average count of nematode ova per gram of feces was 350 in June 1933, the beginning of the experiment, and 85 in June 1934, the end of the experiment.

Table 3 shows the condition of each sheep and the count of nematode ova per gram of feces for the 4 untreated sheep at the beginning and end of the experiment. The average count of nematode ova per gram of feces was 75 for June 1933, the beginning of the experiment, and 3400 in June 1934, the end of the experiment.

*The analysis was made by Dr. R. B. Dustman, head of the department of agricultural chemistry, West Virginia Agricultural Experiment Station. 


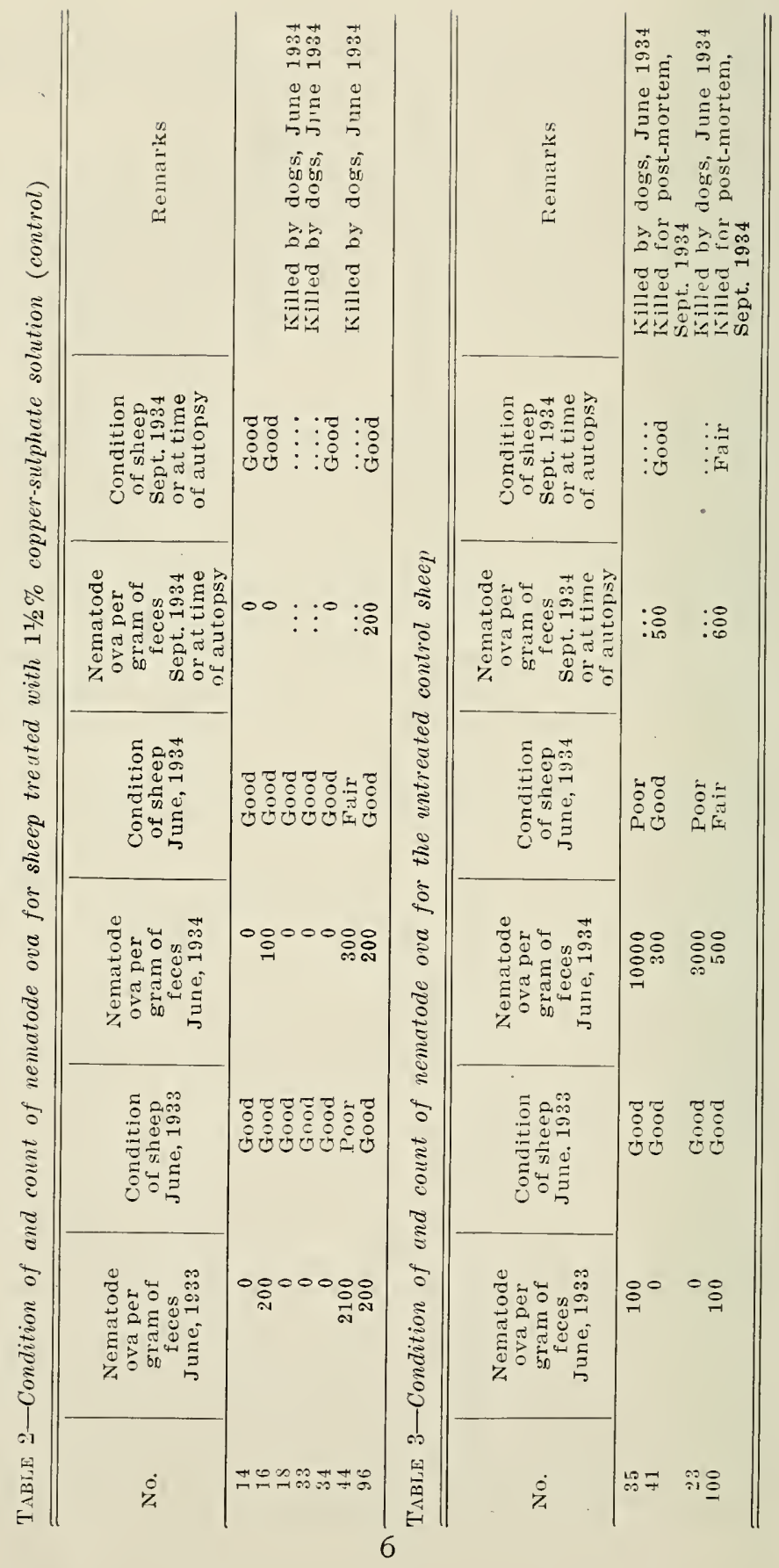


Becanse of the loss from poisoning of two sheep, nos. 6 and 3 , from the lot receiving the $1: 30$ mixture of copper sulphate and salt, the proportion of copper sulphate to salt was reduced from 1:30 to 1:50 in June 1934. The condition of the sheep and the count of nematode ova per gram of feces for the three lots of sheep in this experiment will be found in Tables 1, 2, and 3 for June 1934, bearing data on the beginning of the feeding of the 1:50 copper-sulphatesalt mixture as well as the end of the feeding of the 1:30 mixture.

Table 1 shows the condition of the sheep receiving the coppersulphate-salt mixture and the count of nematode ova per gram of feces for June 1934 and September 1934, the beginning and end of the feeding of the 1:50 mixture.

The average count of nematode ova per gram of feces for this lot was 1100 in June 1934 and 4500 in September 1934, the beginning and termination of the feeding experiment. During this three-month period the average count of nematode ova per gram of feces had increased from 1100 to 4500 , and the general condition of the flock had decreased materially.

Three weeks after changing the copper-sulphate-salt mixture from $1: 30$ to $1: 50$, sheep no. 4 was found dead in the pasture. This sheep did not show symptoms of sickness on the previous day, when seen by the attendant. The autopsy of this sheep showed a general icterus; liver enlarged, soft, and yellow; kidneys swollen, dark, and soft; bladder hemorrhagic, and contents a dark-brown liquid. The diagnosis was poisoning from feeding an excessive amount of copper sulphate.

\section{SUPPLEMENTARY EXPERIMENT}

In September 1934 the mass feeding of the copper-sulphate-salt mixture was discontinued. The 12 ewes surviving in this experiment with their 11 spring lambs were divided into two lots. Lot 1, consisting of 5 ewes and 5 lambs, was treated with a $1 \frac{1}{2} \%$ solution of copper sulphate at intervals of 21 days, beginning September 26, 1934. The adults received 3 ounces each as a drench. The lambs received 2 ounces on September 26;21/2 ounces on October 17 and on November 7 ; and 3 onnces each from November 28 to the end of the experiment on February 20, 1935. Lot 2, consisting of 7 ewes and 6 lambs, was treated with a mixture of equal parts of a $1 \frac{11 / 2}{2} \%$ solution of copper sulphate and a $11 / 2 \%$ solution of nicotine sulphate (Blackleaf 40) at intervals of 21 days beginning September 26, 1934. The adults received 3 ounces each as a drench. The lambs received 2 ounces each on September 26;21/2 onnces each on October 17 and on November 7 ; and 3 ounces each from November 28 to the end of the experiment on February 20, 1935.

Table 4 shows the condition of the sheep and the count of nematode ova per gram of feces for each sheep in Lot 1 . These sheep received the $1 \frac{1}{2} \%$ solution of copper sulphate from September 26, 


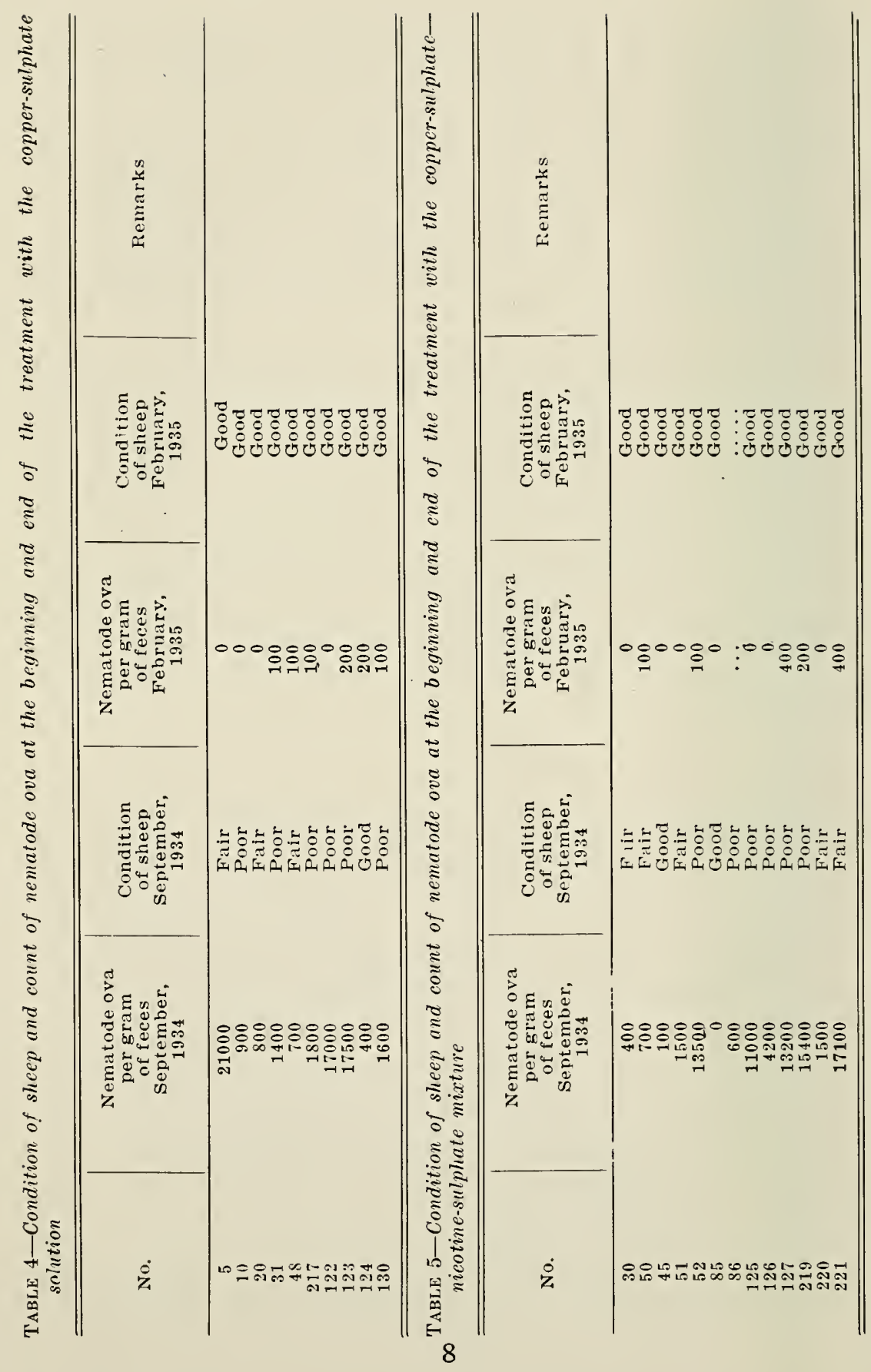


1934, the beginning, to February 20, 1935, the end of the period of treatment. The average count of nematode ova per gram of feces was 6300 on September 26, 1934, and 80 on February 20, 1935, the termination of the experiment.

Table 5 shows the condition of the sheep and the count of nematode ova per gram of feces for each shcep in Lot 2. These sheep received a mixture of equal parts of a $11 / 2 \%$ solution of copper sulphate and a 11/2\% solution of nicotine sulphate (Blackleaf 40) for September 26, 1934, the beginning, and February 20, 1935, the end of the period of treatment. The average count of nematode ova per gram of feces was 6000 on September 26, 1934, and 100 on February 20,1935 , the termination of the treatments.

The general condition of both lots improved materially during the period of treatment from September 1934 to February 1935, as shown in Tables 4 and 5 .

At the time of the September 1934 examination of the feces in Lots 1 and 2, tapeworm segments were recorded for sheep nos. 31, 122,124 , and 130 in Lot 1 , which subsequently were treated with a $11 / 2 \%$ solution of copper sulphate, and sheep nos. 86, 125, 127, 220, and 221 in Lot 2, which subsequently were treated with a mixture of equal parts of a $11 / 2 \%$ solution of copper sulphate and a $11 / 2 \%$ solution of nicotine sulphate (Blackleaf 40). The feces in Lots 1 and 2 were examined on November 7, 1934, and again on February 20, 1935, the time of the termination of the experiment. No tapeworm segments were found at either of these examinations.

\section{SUMMARY}

Twenty sheep were mass-fed or allowed access to a mixture of copper sulphate and salt, $1: 30$. They showed an average of 150 nematode ova per gram of feces at the time the feeding was begun. One year later the average count of nematode ova in the feces was 1100 per gram, or an increase of over $600 \%$ in nematode ova. Even with this increase in nematode infestation the condition of the flock remained good. During this period two sheep died of poisoning from excessive amounts of copper sulphate.

A change in the proportion of copper sulphate to salt from 1:30 to $1: 50$ resulted in an increase of nematode ova in the feces from 1100 to 4500 ova per gram in three months. This was an increase of slightly more than $300 \%$ in nematode ova. One sheep died from poisoning three weeks following the reduction in the proportion of the copper sulphate in the mixture.

The 7 sheep in the treated control lot, or those receiving a $11 / 2 \%$ solution of copper sulphate every 21 days, showed a decrease in the average count of nematode ova in the feces from 380 to 50 per gram, and the condition of the sheep had improved over the period of one year.

The 4 sheep in the untreated control lot showed an average increase in the nematode ova in the feces from 50 to 3400 per gram; 
these sheep also showed a marked decline in their condition during this one-year period.

As a further check on the effectiveness of regular drenching versus mass feeding, the 12 ewes and their 11 lambs were divided in to two lots as nearly uniform as possible. One lot was treated with a $1.1 \% 2 \%$ solution of copper sulphate and the other with a mixture of equal parts of a $1 \frac{1}{2} \%$ solution of copper sulphate and a $1 \frac{1}{2} \%$ solution of nicotine sulphate (Blackleaf 40).

In the lot receiving the copper-sulphate solution the nematode ova count was reduced from 6300 to 80 . In the lot receiving the mixture of copper sulphate and nicotine sulphate the nematode ova were reduced from 6000 to 100 per gram. These treatments covered a period of eight months.

Tapeworm segments disappeared from the stools equally well in the lots treated with copper sulphate and the copper-sulphatenicotine-sulphate mixture.

\section{CONCLUSIONS}

While the number of sheep in this experiment was small, the results would indicate that the mixture of copper sulphate and salt, $1: 30$, when fed to sheep ad libitum and consumed at the rate of onehalf pound per sheep per month, did not adequately control the development of nematode parasites in the gastro-intestinal tract, yet caused the death of sheep from poisoning. A mixture of copper sulphate and salt 1:50 was wholly inadequate in controlling nematode parasites in the gastro-intestinal tracts of these sheep.

The $11 / 2 \%$ solution of copper sulphate and the mixture of equal parts of a $11 / 2 \%$ solution of copper sulphate and a $11 / 2 \%$ solution of nicotine sulphate were equally efficient in the control of nematode infestation. Cestode infestation also disappeared equally under the two treatments. 


\section{LITERATURE CITED}

(1) BeLL, D. S.

1926. STOMACII WORMS AND NodUlar wORMs in rambs. Ohio Agr. Exp. Sta. Bul. 401.

(2) BeLL, D. S.

1935. Personal communication. Ohio Agr. Fixp. Sta.

(3) Boughton, I. B., and HARDY, W. T.

1934. CHRONIC COPPER-SULPIATE POISONING in sheEr. Texas Agr. Exp. Sta. Bul. 499.

(4) Evvard, J. M., Brown, L. C., Culbertson, C. C., and Hammond, W. E.

1926. THE SALT CONSUMPTION OF SIIEEP AND FATTENING LAMBS. Towa Agr. Exp. Sta. Res. Bul. 94.

(5) HARDY, W. T., and SCHMIDT, H.

1932. STOMACI wORMS in SHeEP ANd goats. Texas Agr. Exp. Sta. Bul. 448.

(6) Hutcheson, D.

1891. THE treatment of Wike worms. Agr. Jour. Good Hope $4: 8-9$. South Africa.

(7) NighberT, E. M.

1932. CONTRolling stomach worms in Sheep and Lambs. U. S. Dept. of Agr., B. A. I. Leaflet No. 89.

(8) RIETZ, J. H.

1935. COPPER SULPHATE AS AN ANTHELMINTIC FOR GASTRO-INTESTINAL Parasites of Sheer. W. Va. Agr. Exp. Sta. Bul. 264 (Out of print).

(9) Stoll, N. R.

1923. INVESTIGATIONS ON THE CONTROI. OF HOOKWORM DISEASE: XV. AN EFFECTIVE METHOD OF COUNTING HOOKWORM EGGS IN FECES. Am. Jour. Hyg. $3: 59-70$. 

